\title{
Modulation of the initial growth of Eucalyptus clones using paclobutrazol: when smaller is better
}

\author{
Saad Miranda Silva dos Santos ${ }^{1}$, Sylvana Naomi Matsumoto ${ }^{2 *}$, Ricardo Andrade e Silva ${ }^{3}$, Luan Santos de \\ Oliveira ${ }^{4}$, Anselmo Eloy Silveira Viana ${ }^{1}$
}

${ }^{1}$ Cortez Engenharia Limitada, Avenida João Paulo $1^{\circ}$, no 425, Bairro Nobre, CEP 46100-000, Brumado, Bahia, Brazil

${ }^{2}$ Universidade Estadual do Sudoeste da Bahia, Campus Vitória da Conquista, CP 95, CEP 45000-000, Vitória da Conquista, Bahia, Brazil

${ }^{3}$ Faculdades Arnaldo Horácio Ferreira, Rua Pará, no 2280 - 7 Mimoso I, CEP 47850-000, Luís Eduardo Magalhães, Bahia, Brazil

${ }^{4}$ Universidade Estadual Paulista Júlio de Mesquita Filho,Programa de Pós Graduação em Agronomia, Fazenda Lageado, Rua José Barbosa de Barros, no 1780,CEP 18610-307, Botucatu, São Paulo, Brazil

\section{*Corresponding author: snaomi@uesb.edu.br}

\begin{abstract}
Modulating the growth rates of Eucalyptus during the initial vegetative phase via plant growth regulators can improve field establishment. The objective of this study was to verify the impacts of different concentrations of paclobutrazol (PBZ) on two Eucalyptus hybrids during the initial phase of growth. Experiments were conducted in a greenhouse using an $E$. urophylla $x E$. grandis hybrid (AEC 1528) and a spontaneous hybrid of $E$. urophylla (144 AEC). Both clones were subjected to PBZ concentrations of $0,50,100,150$ and $200 \mathrm{ppm}$ active ingredient (a.i.) applied to the soil. The treatments were part of a $2 \times 5$ factorial design, and they were arranged into randomized blocks and consisted of five replicates. Cuttings were transplanted into 20-L pots; each pot contained one cutting and was considered an experimental unit. At90 days after the application of PBZ, the growth and development of both Eucalyptus clones subjected to all concentrations were inhibited. The inhibition effects intensified as the concentration of PBZ increased until approximately 90 to146 ppm and increased the plant sturdiness ratio (H/D; S//diameter) due to the inhibition of height caused by PBZ. Clone AEC 144 performed better than clone AEC 1528with respect to dry mass accumulation, LN and leaf area. However, clone AEC 1528 was superior with respect to resource partitioning due to a lower S/R ratio, aiding survival underwater deficit conditions.
\end{abstract}

Keywords: Growth regulators, Gibberellin inhibitor, E. urophylla, E.grandis.

Abbreviations: PBZ_ paclobutrazol, $H_{-}$height, $S_{-}$stem diameter, $L S N_{-}$lateral shoot number, LN _ leaf number, TLA_total leaf area, H/D_ sturdiness ratio, LDM _ leaf dry mass, STM _ stem dry mass, S_ shoot dry mass, R _ root dry mass, S/R _ (shoot:root

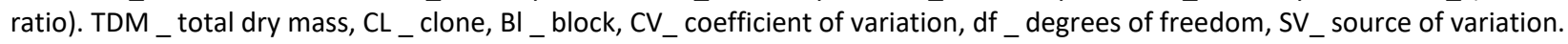

Introduction

In 2015, the area occupied by forest plantations in Brazil surpassed9 million hectares, and $74.9 \%$ of this area corresponds to Eucalyptus plantations (Sidra, 2017), indicating the importance of this species. Hybrids of the cross between Eucalyptus urophylla x Eucalyptus grandis constitute $80 \%$ of Brazilian clonal plantations. Great potential for the development of Eucalyptus crops in the southern and southeastern regions of the country exists due to favorable environmental conditions in those regions and the proximity to industry, facilitating the logistics of planting, harvesting and commercializing raw Eucalyptus materials. The use of fast-growing species such as Eucalyptus in marginal environmental areas has been explored to both expand the boundaries of planted forests and meet demand for timber production, mainly that destined for energy purposes. To overcome the adversities of these alternative areas, selection of Eucalyptus clones that are better adapted to these environmental limitations remains the only strategy employed. However, the application of management practices, especially immediately after planting, to these hardier, better-adapted clones maybe an important strategy. In semi-arid regions, even when initial water is supplied, plant water maintenance cannot be optimized due to high evapotranspiration, as the capacity of water uptake by the roots and the hydraulic conductivity of the soil cannot compensate for the transpirations loss from the aerial parts of plants (Monteiro, 2009). Restricted water availability is a factor that modulates plant phenotypic plasticity and results in morphological and physiological changes, including leaf senescence, mass reduction, increased stomatal resistance and reduced photosynthetic capacity (Bongers et al., 2017). While these changes weaken plant water status, they can lead to reduced vigor if they occur during the early stages of plant growth, resulting in an irreversible restriction of wood 
yield potential. One way to interfere in this phenotypic plasticity interaction could be through the management of plant growth regulators. Altering source/sink relationships can improve water status by fine tuning plant redox homeostasis, as proposed by Srivastava et al. (2016), and is applicable to field management, mainly during the initial growth of plants.

Among the various plant growth regulators, paclobutrazol (PBZ) acts mainly by reducing plant growth rates, enhancing protection against disease (Roberts et al., 2016, Miller, 2016)and increasing tolerance to water stress (Mohammadi et al., 2016). The PBZ mode of action involves the inhibition of gibberellic acid synthesis, resulting in metabolic changes in abscisic acid, cytokinins, and ethylene as well as altered auxin levels (Hedden and Thomas, 2016). Furthermore, PBZ can alter source/sink relationships, intensifying the transport of photoassimilates to the root system (Nivedithadevi et al., 2012), stimulating the generation of adventitious roots (Negishi et al., 2011), and increasing the capacity of plants to absorb water from the soil. PBZ also restricts the growth of the plant aerial parts (Pardos et al., 2005), reducing the transpirational area. This reduced transpirational leaf surface area and the increased water absorption from the soil to the roots improves plant water status.

Changes promoted by PBZ depend on species, variety and plant development stage as well as PBZ concentration and application method (Silva and Faria Jr, 2011). Regarding Eucalyptus cultivation, PBZ shortens the juvenile stage and stimulates the reproductive phase, resulting in early flowering (initiation of flower buds) (Moraes et al.,2014; Gardner et al., 2016; Klocko et al., 2016; Potts et al., 2008). The effects of PBZ on Eucalyptus growth were first reported in the 1990s (Willians et al., 1999; Griffin et al., 1993). However, little knowledge exists regarding the use of PBZbased management practices to modify the architecture of Eucalyptus plants under field conditions. Therefore, the goal of this study was to evaluate the effects of different concentrations of PBZ on the morphological changes of two Eucalyptus hybrid clones during their initial growth phase.

\section{Results and Discussion}

\section{General aspects of plants subjected to PBZ}

Morphological alterations of both Eucalyptus clones were evident ninety days after PBZ application; these alterations resulted in highly different morphological plant architectures (Supplementary Fig.1).

Both clones subjected to PBZ exhibited clear toxicity symptoms, such as shoot compactness and drastically shortened principal and lateral stems (Supplementary Fig.1a and $1 \mathrm{~b}$ ).Thickening of the root system was also observed. All concentrations of PBZ resulted in enlarged diameters of secondary roots in regions near the PBZ application sites, as previously reported by Siqueira et al. (2008) regarding the early growth of the lemon variety Volkameriano (Supplementary Fig.1c).

The impact of PBZ on plant growth was verified via the analysis of variance for the majority of characteristics, excluding leaf dry mass (LDM) and the shoot/root dry mass ratio (S/R) (Table 1). Clonal responses were observed for all dry mass measurements, including the number of leaves, the total leaf area of the shoot (TLA), and the dry mass ratio of the aerial parts of the plant to the roots $(S / R)$. Interactions between regulator concentrations and clones were observed only for LN and TLA (Table 1).

\section{Morphological characteristics}

Second-order quadratic models defined the relationships between PBZ concentration and plant height $(\mathrm{H})$, stem diameter (SD), the number of lateral shoots, the sturdiness ratio $(H / D), L D M$, the STM, R, S and TDM for the combined data for each clone(AEC 1528 and AEC 144)(Fig.1). Reduced $\mathrm{H}, \mathrm{STM}$, and TDM were the most striking effects of PBZ on Eucalyptus plants. Compared with the $\mathrm{H}$ of control plants, the $\mathrm{H}$ of plants treated with PBZ was at most $51.67 \%$ lower; this maximum was achieved using a PBZ concentration of 140 ppm (Fig.1a). Reduced $\mathrm{H}$ is a common effect of PBZ application in some Eucalyptus species and is associated with shortened internodes (Moraes et al., 2012; Moraes et al., 2014).

The inhibition of stem elongation by PBZ is a result of the restricted biosynthesis of GA1 (biologically active gibberellin), which is responsible for stem growth via activation of GA2 oxidase (Lo et al., 2008; Rieu et al., 2008). Another mechanism of PBZ action involves the accumulation of DELLA proteins. This accumulation inhibits the action of gibberellins (Zheng et al., 2016).

Compared with the SD of control plants, the SD of plants treated with PBZ was at most $21.62 \%$ lower; this maximum was achieved using a PBZ concentration of 60 ppm (Fig.1b). Among all morphological characteristics studied, the SD of plants treated with the highest estimated concentration of PBZ was the least inhibited. Low inhibition effectiveness on SD is related to the lack of gibberellin biosynthesis in the vascular cambium (Leopold and Kriedemann, 1975) and to the lower expression of secondary growth during the change in the growth phase. Reduced SD due to the application of PBZ has also been reported in Pinus nigra, Betula papyrifera (Chorbadjian et al., 2011), Eucalyptus camaldulensis and Eucalyptus tereticornis (Varghese et al., 2008)as well as E. grandis during the initial growth stage (Moraes et al., 2014). Similar reductions $(25.24 \%)$ in lateral shoot number (LSN) were observed in plants treated with PBZ concentrations of $116 \mathrm{ppm}$ and in control plants (Fig.1c). PBZ-induced restriction of LSN in ornamental herbaceous peony is associated with a reduction in metabolic energy due to the reduced metabolism and transport of carbohydrates to lateral shoots (Zhao et al, 2015). Thus, sucrose reductions promoted by all concentrations of PBZ may result in higher LSN in treated plants than in control plants.

At all concentrations of PBZ, the H/D was lower in the PBZtreated plants than in the control plants. Compared with the H/D of control plants, the H/D of plants treated with PBZ was at most $49.18 \%$, resulting in a ratio of 3.13 ; this maximum was achieved using a PBZ concentration of 180 ppm (Fig.1f). A high H/D is indicative of a relatively tall and slender plant, whereas a low ratio suggests a short and stout plant (Hasan and Reid, 1995). The reduction in this ratio is mainly attributed to the higher efficiency of PBZ with respect to inhibiting growth in $H$. A lower $H / D$ is particularly favorable in areas of low rainfall: the lower the value is, the more robust the plant (Grossnickle, 2012) and therefore the greater the potential for survival in the field. However, the $H / D$ values observed in this study were lower than the ideal 
Table 1. Summary of the variance analysis of E. urophylla $\times$ E. grandis hybrid (AEC 1528) (a) and a spontaneous hybrid of $E$. urophylla (144 AEC) growth characteristics and dry mass parameters in function to source of variation (SV) defined as pacobutrazol concentrations and clones, evaluated at 90 days after application of the regulator. Mean Squares

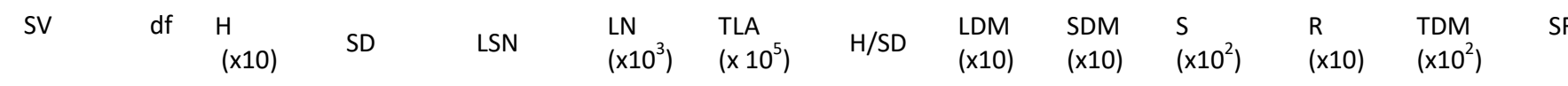

\begin{tabular}{|c|c|c|c|c|c|c|c|c|c|c|c|c|c|}
\hline PBZ & 4 & 254.01 & $6,43^{* * *}$ & $39,51^{* 2 *}$ & $17.11^{* *}$ & $4.82^{* 2}$ & $11.52^{* *}$ & 4.11 & $88.42^{* 2 *}$ & 13.20 & $43.70^{* 2}$ & $30.80^{* *}$ & 5.0 \\
\hline $\mathrm{CL}$ & 1 & 5.33 & 2,51 & 0,91 & $248.22^{* *}$ & $150.11^{* *}$ & 0.01 & $27.12^{* *}$ & $39.53^{* *}$ & $12.23^{* *}$ & $27.20^{* *}$ & $2.80^{* *}$ & $8.0^{*}$ \\
\hline PBZXCl & 4 & 6.20 & 0.66 & 6.10 & $15.00^{*}$ & $12.27^{*}$ & 0.51 & 7.53 & 1.60 & 1.43 & 5.23 & 3.41 & 5.1 \\
\hline $\mathrm{BI}$ & 4 & 13.00 & $3.20^{*}$ & $37.54^{*}$ & $20.62^{* *}$ & $13.19^{*}$ & 1.12 & $10.66^{*}$ & 1.95 & 0.62 & 1.62 & 2.52 & 3.0 \\
\hline Resid. & 36 & 5.22 & 1.10 & 6.95 & 3.11 & 4.40 & 0.41 & 2.97 & 1.41 & 1.51 & 2.93 & 1.41 & 3.1 \\
\hline${ }^{1} \mathrm{CV}(\%)$ & & 14.52 & 9.93 & 20.76 & 19.14 & 17.00 & 13.92 & 16.64 & 21.12 & 15.65 & 15.22 & 13.72 & 12.3 \\
\hline
\end{tabular}

(a)

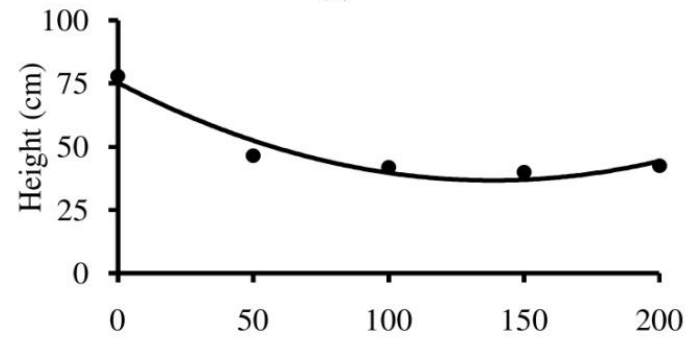

(b)

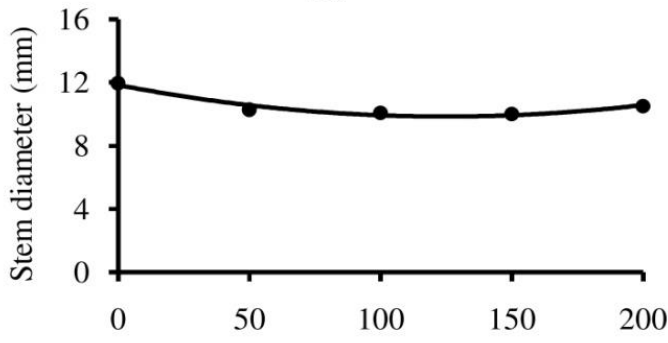

PBZ concentration (ppm)

$\hat{\mathrm{Y}}^{*}=75.32+0.56 \mathrm{X}+2.13 \times 10^{-3} \mathrm{X}^{2}\left(\mathrm{R}^{2}=0.94\right)$

(c)

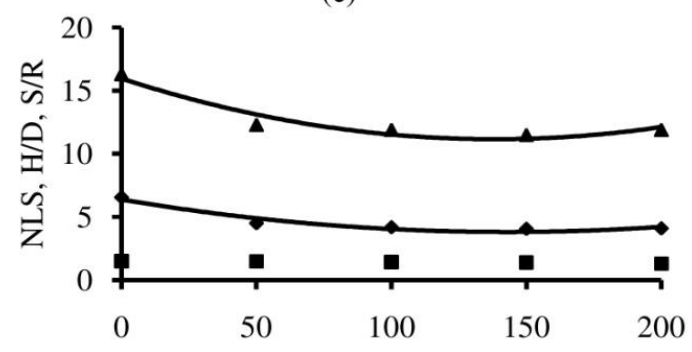

$\hat{\mathrm{Y}}^{*}=11.84-0.03 \mathrm{X}+0.10 \times 10^{-3} \mathrm{X}^{2}\left(\mathrm{R}^{2}=0.95\right)$

(d)

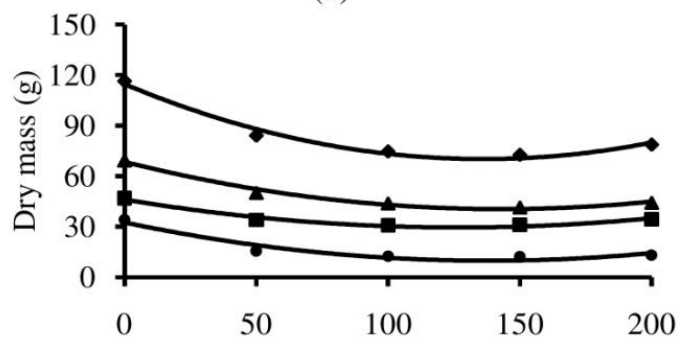

PBZ concentration (ppm)

$\Delta, \mathrm{NLS}: \hat{\mathrm{Y}}^{*}=15.96-6.95 \times 10^{-2} \mathrm{X}+0.03 \times 10^{2} \mathrm{X}^{2}\left(\mathrm{R}^{2}=0.93\right)$

•,H/D: $\hat{Y}^{*}=6.37-3.61 \times 10^{-2} \mathrm{X}+0.01 \times 10^{-2} \mathrm{X}^{2}\left(\mathrm{R}^{2}=0.94\right)$

a, $\mathrm{S} / \mathrm{R}: \overline{\mathrm{Y}}=1.42$
•, TDM: $\hat{\mathrm{Y}}^{*}=114.59-0.65 \mathrm{X}+0.24 \times 10^{-2} \mathrm{X}^{2}\left(\mathrm{R}^{2}=0.98\right)$

$\Delta, \mathrm{S}: \quad \hat{\mathrm{Y}}^{*}=68.47-0.39 \mathrm{X}+1.40 \times 10^{-3} \mathrm{X}^{2}\left(\mathrm{R}^{2}=0.99\right)$

a, R: $\quad \hat{Y}^{*}=46.12-0.26 \mathrm{X}+0.12 \times 10^{-2} \mathrm{X}^{2}\left(\mathrm{R}^{2}=0.97\right)$

$\bullet, \mathrm{SDM}: \hat{\mathrm{Y}}^{*}=32.52-0.33 \mathrm{X}+0.12 \times 10^{-2} \mathrm{X}^{2}\left(\mathrm{R}^{2}=0.93\right)$ (e)

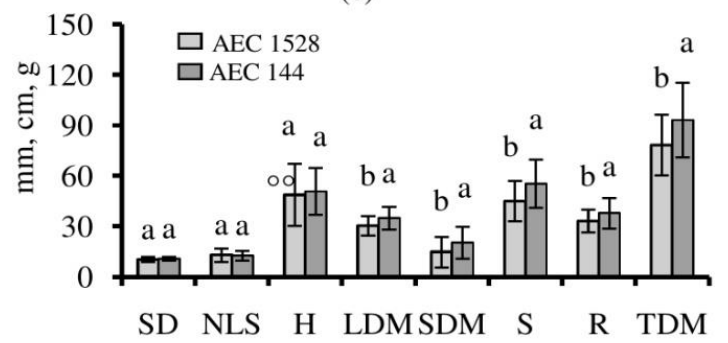

(f)

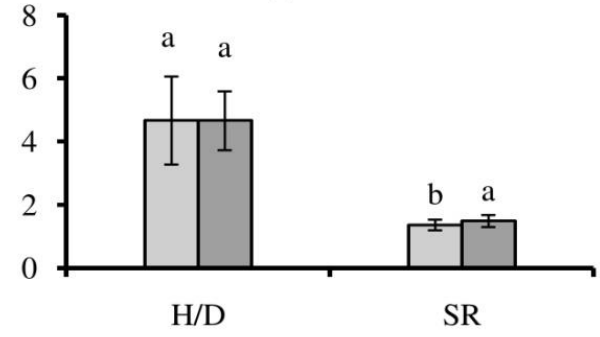

Fig 1. Regression models for morphological characteristics at 90 days after transplanting: (a) height, (b) stem diameter, (c) number of lateral shoots, (d) sturdiness ratio and for various dry mass components: (e) stem dry mass, (f) shoot dry mass, (g) root dry mass and (h) total dry mass for two Eucalyptus clones, (AEC 1528 and 144) subjected to PBZ concentrations. *Significant at 5\%, by variance analysis of regression. Different letters indicate differences by Tukey test, with 0.05 probability. Columns represent means $(n=25)$ and bars correspond to the mean standard error. 
(a)

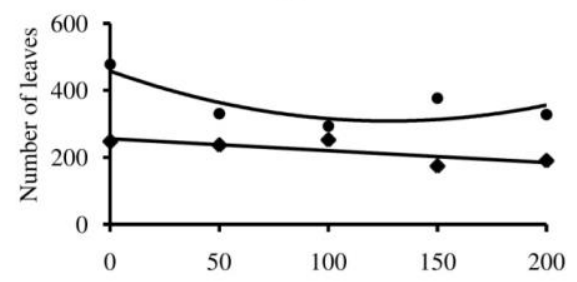

(b)

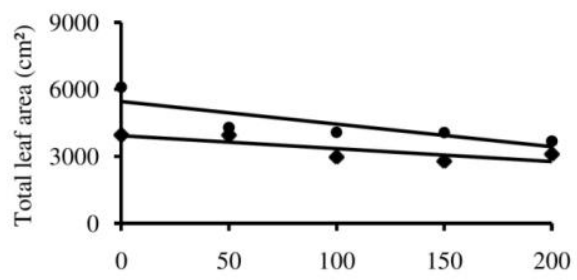

PBZ concentration (ppm)

- $\hat{\mathrm{y}}^{*}=457.73-2.33 \mathrm{x}+0.91 \mathrm{x} 10-2 \mathrm{x}^{2}\left(\mathrm{R}^{2}=0.66\right)$

- $\hat{y}^{*}=256.04-0.36 x\left(r^{2}=0.62\right)$

- $\hat{y}^{*}=5459.11-10.13 x \quad\left(r^{2}=0.71\right)$

- $\hat{y}^{*}=3928.32-5.78 x\left(\mathrm{r}^{2}=0.66\right)$

(d)

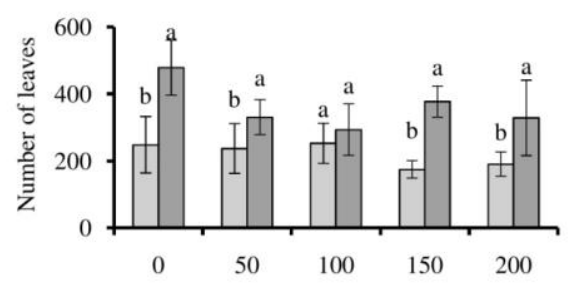

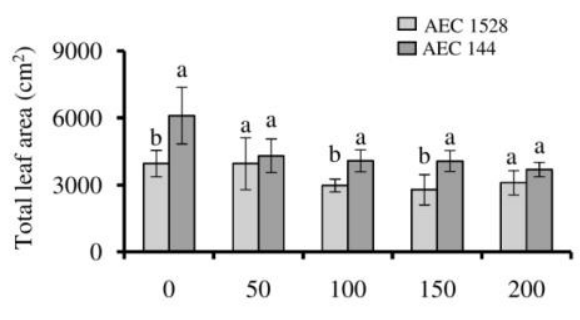

PBZ concentration (ppm)

Fig 2.Regression models for morphological characteristics at 90 days after transplanting: (a) number of leaves and (b) leaf area of clones, AEC $1528(\bullet)$ and AEC $144(\bullet), 90$ days after the transplantation in relation to PBZ concentrations applied. *Significant at $5 \%$, by variance analysis of regression. Different letters indicate differences by Tukey test, with 0.05 probability. Columns represent means $(n=5)$ and bars correspond to the mean standard error.

range of values (5.4 to 8.1)for Eucalyptus proposed by Trigueiro and Guerrini (2003).

Relationships between the concentrations of PBZ and the STM, S, and R as well as the combination of all these components were established in accordance with secondorder polynomial models; these models were characterized by decreases in dry mass when PBZ in the range of 130-139 ppm was used $(137.04,139.4,130.65$ and $138.69 \mathrm{ppm}$, respectively, Fig.1d). The dry mass accumulation of the control plants remained higher than that of plants treated with PBZ, resulting in dry mass percentage reductions of $69.29 \%, 21.3 \%, 37.02 \%$ and $61.28 \%$ for the STM, S, R and TDM, respectively (Fig.1d). Among the dry mass parameters analyzed, STM was more sensitive to PBZ (Fig.1d). This high inhibition rate was due to altered shoot morphology, which was characterized by a reduction in $\mathrm{H}$ and $\mathrm{SD}$, therefore reducing growth. PBZ was also active in the shoot apical meristems and inhibited gibberellins, which are responsible for cell development and elongation (Taiz and Zeiger, 2013). Similar results were obtained by Siqueira et al. (2008), who applied PBZ to Volkameriano lemon plants during their initial growth and reported that $S$ was $45.25 \%$ lower in the plants treated with $193.08 \mathrm{mg}$ plant ${ }^{-1} \mathrm{PBZ}$ than in the control plants. This value is two times greater than the $21.3 \%$ inhibition observed in the present study (Fig.1d).

Among the various PBZ-promoted dry mass parameters analyzed, reductions in $\mathrm{R}$ were intermediate. According Pardos et al. (2005), uncertainty still remains regarding the action of PBZ on root growth. Thus, root growth inhibition may directly result from exposure to PBZ in the soil or may be a secondary result of shoot growth restriction. Those authors reported that increasing concentrations of PBZ applied to the soil result in decreased R of Quercus suber $\mathrm{L}$. seedlings; the R was $67 \%$ lower in the PBZ-treated plants than in the control plants. Abod and Yasin (2002) reported that the root dry mass of Acacia mangium seedlings at 12 weeks after PBZ exposure was $12 \%$ lower in the PBZ-treated plants than in the control plants.

The TDM inhibition was similar to that of SDM. This similarity was associated with the high contribution of stem tissue during the early development with respect to plant mass accumulation. However, Siqueira et al. (2008) reported that TDM reduction is primarily related to the $S$ reduction because the latter parameter corresponds to a higher proportion of plant dry mass.

With respect to the dry mass measurements, differences in the accumulation of mass between the clones were observed, and these differences were independent of PBZ concentration (Fig.1e). No effect of PBZ concentration was observed for LDM.

Clonal effects were evident for all the dry mass parameters measured; higher mean values were observed for clone AEC 144 than for AEC 1528 (Fig.1e). Increased growth of clone AEC 144 was also reported in studies by Reis et al. (2014) and Pinto et al. (2011). Although the potential dry mass accumulation for clone AEC 1528 was lower than that for clone AEC 144, the lower S/R dry mass ratio for clone AEC1528 is beneficial in regions that experience water deficits and have low soil fertility (Fig. 1f). The lower S/R ratio enables the maximization of the water supply available to plants (Pinto et al., 2011). However, the growth changes induced by PBZ applications need to be studied further to elucidate the extensive effects of the interactions between this regulator and the clones (Rodrigues et al., 2016).

Differences in clone sensitivity were observed for leaf number (LN) and TLA as a function of PBZ concentration (Fig.2). The discrepancy regarding the number of leaves resulted in the generation of different models for each 
clone. A negative linear regression model was fitted for AEC 1528 , whereas a second-order polynomial regression model reflected the trend for clone AEC 144(Fig.2a).

For each clone, the TLA decreased linearly as the PBZ concentration increased; the TLA values for clones AEC 144 and AEC 1528 were $37.1 \%$ and $29.4 \%$ lower than those of the control, respectively (Fig.2b). However, a more intense response to increasing $\mathrm{PBZ}$ concentration was observed for clone AEC 144 than for clone AEC 1528; this response was verified by the large absolute values of the slope coefficients of the equations ( -10.13 vs -5.78 , respectively).

The number of leaves and individual leaf area are the main factors that determine the TLA. For both clones, a decrease in the TLA was observed as a function of increasing concentrations of PBZ. For clone AEC 144, the number of leaves increased in response to128.05 ppm PBZ and resulted in a reduction in individual leaf area (Fig.2a and 2b). Navarro et al. (2007) attributed the reduction in the number of leaves in Arbutus unedo to the reduction in the number of buds caused by the application of PBZ. In addition to its effect on the number of leaves, this inhibits or can induce changes in leaf morphology; in turn, these changes can reduce the transpirational surface area and therefore increase tolerance to environmental stresses (Fletcher et al., 2010).

The results of the analysis of the number of leaves per clone showed that more leaves occur in clone AEC 144 than in clone AEC 1528, and more leaves occur in the clones in response to all the concentrations of PBZ than in the controls, with the exception of the $100 \mathrm{ppm}$ treatment (Fig.2c). PBZ was particularly effective at reducing the number of leaves of clone AEC 144. Similarly, the results of the leaf area analysis showed that the values of clone AEC 144 were significantly higher than those of clone AEC 1528 at 0,100 and $150 \mathrm{ppm}$, but no differences were evident at 50 or 200 ppm (Fig.2d). Zhou et al. (2012) and Rodrigues et al. (2016) studied the effects of PBZ on Tectona grandis and reported that higher concentrations of PBZ induced thicker leaflets that had scleromorphic characteristics that were similar to the leaves of Toona ciliata clones, and genotypic differences among clones (BV1110, BV1321, BV1120 and BV1151) played a role. Cauvin (1991) also reported changes in the length and width of leaves of the hybrid clones of Eucalyptus gunnii $\times E$. grandis, E. urophylla $\times E$. grandis and E. gunnii $\times$ Eucalyptus dalrympleana following application of PBZ. Silva and Faria Jr. (2011) reported that differences depended on the dosages applied and were attributed to the differential sensitivity to PBZ for each species and variety.

\section{Materials and methods}

\section{Location, plant materials and substrate description}

This experiment was carried out from November 2014 until February 2015 at the State University of Southwest Bahia (UESB), which is located in the municipality of the Vitória da Conquista campus in the southwestern region of the state of Bahia, Brazil ( $14^{\circ} 51^{\prime} 58^{\prime \prime}$ South, latitude and $40^{\circ} 50^{\prime} 22^{\prime \prime}$ West, longitude). The average altitude is $923 \mathrm{~m}$, and the area encompasses $3,356.9 \mathrm{~km}^{2}$ (IBGE, 2014). The climate is subhumid to dry. The average annual temperature is $20^{\circ} \mathrm{C}$, and the rainy season in the city occurs from November to January, during which time the annual rainfall is $733.9 \mathrm{~mm}$.
The experiment was conducted in a greenhouse using two hybrid clones. These clones included the E.urophylla $\times E$. grandis clone AEC 1528 and the spontaneous E. urophylla hybrid AEC 144. Both clones were derived from vegetative propagation in the clonal minigardens of Fibria, which is commercialized by Ouro Verde; the gardens are located in Águas Vermelhas, MG,Brazil. Ninety-day-old cuttings were used, and those with four to five pairs of leaves were selected for standardization across treatments. These cuttings were planted in $20-\mathrm{L}$ pots that contained both soil from the surface layer of a Red-Yellow Latosol (Santos et al., 2013) and organic matter from cattle manure at the ratio of $3: 1$, respectively. The soil was supplemented with basic fertilizer macronutrients consisting of $100 \mathrm{mg} \mathrm{N} \mathrm{dm}^{-3}$ soil and $240 \mathrm{mg} \mathrm{P} \mathrm{dm}^{-3}$ soilviaurea and superphosphate, respectively.

\section{Experimental design and treatments}

The experiment was conducted as a randomized block design with five replications in a $2 \times 5$ factorial and consisted of two hybrids (clones AEC 1528 and AEC 144) and five concentrations of PBZ (0, 50, 100, 150 and 200 ppm plant $\left.^{-1}\right)$. Each experimental unit consisted of a pot containing one plant. The PBZ solutions were prepared in $5 \mathrm{~L}$ of distilled water, and a volume of $500 \mathrm{~mL}$ was applied per plant directly to the soil15 days after transplanting the cuttings. According to Rademacher (2016), PBZ is a potent growth regulator and is very persistent in ambient conditions; its average half-life is approximately six months in both plants and soils (Supplementary Fig.2). PBZ is commonly used for its fungicidal activity against ergot formation due to fungi and is particularly used in countries that have warmer climates to control vegetative growth of fruit trees.

\section{Measurement of traits}

Morphological evaluations were performed 90 days after the application of PBZ. H (stem base to the apex of the plant), SD (with DC-60 model, Western, Zhejiang, China, and readings were taken at $3 \mathrm{~cm}$ above the ground), the LSN, LN and TLA were measured. The LSN and LN counts were performed based on visual observations. The TLA encompassed all plant leaves and was determined using a leaf area meter (LI-3100, LI-COR, USA). The STR, which describes the relationship between $\mathrm{H}$ and $\mathrm{SD}$, was determined by the ratio between these two variables and therefore is unit less.

To obtain the LDM, SDM and RDM, those components were first separated and then dried in a forced-air convection oven at $60 \pm 5$ ㅇ $\mathrm{C}$ for 48 hours until constant mass of the samples was achieved. The samples were then individually weighed using a semi-analytical balance $(0.01 \mathrm{~g})$. The $S$ was considered the dry mass of both the stems and leaves, and the TDM was obtained by summing the dry mass of all the measured components. The $S / R$ was also calculated to determine the relationship between the dry weight of the shoots and roots, and therefore is unit less.

\section{Statistical analysis}

The data were subjected to the analysis of variance by the $\mathrm{F}$ test. When significant interactions between treatment factors were revealed, the simple effects were analyzed. The main effects of variables that did not significantly interact 
were also analyzed. The means were compared by the Tukey test at the $5 \%$ level of error probability, and mathematical model were established by regression analysis of variance. Procedures were performed using Statistical and Genetic Analysis, SAEG version 9.1. The adjustments of the mathematical equations were based on the regression analysis of variance and the coefficients of determination $(\geq$ $60 \%)$.

\section{Conclusion}

PBZ applied to substrate inhibits the development and growth of Eucalyptus hybrid clones. As PBZ concentration increased, the effect intensified, up to a concentration of approximately $146 \mathrm{ppm}$. A lower STR ratio was observed in the STR-treated plants than in the control plants; a lower ratio increases the robustness of plants. Compared with clone AEC 1528, clone AEC 144 has a greater ability for dry mass accumulation as well as increased number of leaves and leaf area, even under applications of PBZ. However, in comparison to clone AEC 144, clone AEC 1528 has a lower $S / R$, indicating better distribution of mass between the shoots and root system.

\section{Acknowledgments}

The authors would like to thank the Coordination for the Improvement of Higher Education Personnel (CAPES), the UESB and the National Council for Scientific and Technological Development (CNPq) for the scholarship granted for this study. Sylvana $\mathrm{N}$ Matsumoto gratefully acknowledges the CNPq, Brazil, for the concession of a fellowship of scientific productivity.

\section{References}

Abod SS, Yasin S (2002) Effects of paclobutrazol and daminozide on the growth of Acacia mangium seedlings. JTAS. 25 (2): 143-147.

Bongers FJ, Olmo M, Lopez-Iglesias B, Anten NP, Villar R (2017) Drought responses, phenotypic plasticity and survival of mediterranean species in two different microclimatic sites. Plant Biol. 19: 386-395.

Cauvin B (2001) Effet du paclobutrazole sur la mise à fleurs, la croissance de clones juvéniles d'Eucalyptus. Ann Rech Sylvicoles. 2000: 71-88.

Chorbadjian RA, Bonello P, Herms DA (2011) Effect of the growth regulator paclobutrazol and fertilization on defensive chemistry and herbivore resistance of austrian pine (Pinus nigra) and paper birch (Betula papyrifera). Aust J Forensic Sci. 37 (6): 278-287.

Fletcher RA, Gilley A, Sankhla N, Davis TD (2010) Triazoles as plant growth regulators and stress protectants. Hortic Rev. 24: 55-138.

Gardner, RA, Bertling I, Savage, MJ, Naidoo, S. (2016) Investigating optimal site conditions for flower bud production in Eucalyptus smithii orchards in South Africa. Austr Forest Res. 79 (2): 137-146.

Griffin AR, Whiteman P, Rudge T, Burgess IP, Moncur M (1993) Effect of paclobutrazol on flower-bud production and vegetative growth in two species of eucalyptus. Can J Forest Res. 23 (3): 640-647.
Grossnickle SC (2012) Why seedlings survive: influence of plant attributes. New Forest., 43 (5/6): 711-738.

Hasan O, Reid JB (1995) Reduction of generation time in Eucalyptus globulus. Plant Growth Regul. 17: 53-60.

Hedden P, Thomas SG (2016) Annual plant reviews, the gibberellins. John Wiley and Sons.

Klocko CM, Ma C, Robertson S, Esfandiari E, Nilsson O, Strauss SH. (2016) FT overexpression induces precocious flowering and normal reproductive development in eucalyptus. J Plant Biot. 14 (2): 808-819.

Leopold CA, Kriedemann PE (2015) Plant growth and development. McGraw-Hill, New York.

Lo SF, Yang SY, Chen KT, Hsing YL, Zeevaart JAD, Chen LJ, Yu SM (2008) A novel class of gibberellin 2-oxidases control semi dwarfism, tillering, and root development in rice. Plant Cell. 20: 2603-2618.

Miller GL (2016) Effect of watered in demethylation-inhibitor fungicide and paclobutrazol applications on foliar disease severity and turfgrass quality of creeping bentgrass putting greens. Crop Prot. 79: 64-69.

Mohammadi MHS, Etemadi N, Arab MM, Aalifar M, Arab M, Pessarakli M (2017) Molecular and physiological responses of iranian perennial ryegrass as affected by trinexapac ethyl, paclobutrazol and abscisic acid under drought stress. Plant Physiol Bioch. 111: 129-143.

Monteiro JE (2009) Agrometeorologia dos cultivos: o fator meteorológico na produção agrícola. INMET, Brasília.

Moraes CB, Carignato A, Uesugi G, Abílio FM, Palomino EC, Mori ES (2014) Variabilidade genética e alterações morfológicas em progênies de polinização aberta de Eucalyptus grandis sob o efeito de paclobutrazol. Científica. 42 (4): 396-403.

Moraes, CB, Zimback L, Uesugi G, Guerrini IA, Mori ES (2012) Alterações morfológicas em Eucalyptus sob a aplicação de biorreguladores. Rev Inst Flo. 24 (2): 251-257.

Navarro A, Sánchez-Blanco MJ, Bañon S (2007) Influence of paclobutrazol on water consumption and plant performance of Arbutus unedo seedlings. SciHorticAmsterdam. 111 (2): 133-139.

Negishi N, Ooishi M, Kawaoka M (2011) Chemical screening for promotion of adventitious root formation in Eucalyptus globules. BMC Proc. 5 (7): 139.

Nivedithadevi D, Somasundaran R, Pannerselvam D (2012) Effect of abscisic acid, paclobutrazol and salicylic acid on the growth and pigment variation in Solanum triobatum (I). IJDDR. 4 (3): 236-246.

Pardos JA, Calama R, Monteiro G (2005) Growth of container-grown cork oak seedlings as affected by foliar and soil application of paclobutrazol. HortScience. 40 (6): 1773-1776.

Pinto SIC, Furtini Neto AE, Lima JC, Faquin V, Moretti BS (2011) Eficiência nutricional de clones de eucalipto na fase de mudas cultivados em solução nutritiva. Rev Bras Cienc Solo. 35 (2): 523-533.

Potts BM, McGowen MH, Williams DR, Suitor S, Jons TH, Gore PL, Vaillancourt RE (2008) Advances in reproductive biology and seed production systems of Eucalyptus: the case of Eucalyptus globulus. South Forest. 70 (2): 145-154.

Rademacher W (2016) Chemical regulators of gibberellin status and their application in plant production. Annu Plant Rev. 49: 359-404. 
Reis CAF, Santos PET, Pauludzyszyn Filho E (2014) Avaliação de clones de eucalipto em Ponta Porã, Mato Grosso doSul. PFB. 34 (80): 263-269.

Rieu I, Eriksson S, Powers SJ, Gong F, Griffiths J, Woolley L, Benlloch R, Nilsson O, Thomas SG, Hedden P, Phillips AL (2008) Genetic analysis reveals that C19-GA 2-oxidation is a major gibberellin inactivation pathway in Arabidopsis. Plant Cell. 20: 2420-2436.

Roberts JA, Ritchie DF, Kerns JP (2016) Plant growth regulator effects on bacterial etiolation of creeping bentgrass putting green turf caused by Acido voraxavenae. Plant Dis. 100(3): 577-582.

Rodrigues LC, Castro EM, Pereira FJ, Maluleque IF, Barbosa, JPRAD, Rosado SCS (2016) Effects of paclobutrazol on leaf anatomy and gas exchange of Toona cilliata clones. Aust Forestry. 79(4): 241-147.

Sidra, Sistema IBGE de Recuperação Automática. Produção da extração vegetal e da silvicultura. Tabela 5930 - Área total existente em 31/12dos efetivos da silvicultura, por espécie florestal. https://sidra.ibge.gov.br/tabela/5930\#resultado Access in May,15, 2017.

Silva KS, Faria Júnior MJA (2011) Uso de paclobutrazol como estratégia para redução do porte e da brotação lateral de plantas de tomateiro. Cienc Agrotec 35 (3): 539-546.

Siqueira DL, Salomão LCC, Cecon PR, Barros ZJ, Fernandes AR (2008) Distribuição da massa de matéria seca em limoeiro 'Volkameriano' submetido a diferentes doses de paclobutrazol e ácido giberélico. Rev Ceres. 55 (6): 512517.
Srivastava AK, Pasala R, Minhas OS, Sprasanna P (2016) Plant biorregulators for sustainable agriculture: integrating redox signaling as a possible unifying mechanism. Adv Agron. 137:237-278.

Taiz L, Zeiger E (2013) Fisiologia Vegetal. Artmed. Porto Alegre.

Trigueiro RM, Guerrini, IA (2003) Uso de biossólido como substrato para produção de mudas de eucalipto. Sci For. 64: 150-162.

Varghese M, Ravi N, Kamalakannan R, Harwood CE (2008) Effect of silvicultural treatments on growth, fertility and capsule traits in seedling seed orchards of Eucalyptus camaldulensis and E. tereticornis. New Forest. 37 (1): 99107.

Worthin CR, Hance RJ (1991) The pesticide manual. The british crop protection council, UK.

Williams DR, Ross JJ, Reidi JB, Potts BM (1999) Response of Eucalyptus nitens seedlings to gibberellins biosynthesis inhibitors. Plant Growth Regul. 27:125-129.

Zhao D, Gong S, Hao Z, Meng J, Tao J (2015) Quantitative proteomics analysis of herbaceous peony in response to paclobutrazol inhibition of lateral branching. Int J Mol Sci. 16 (10): 24322-24352.

Zheng Y, Zhiping G, Ziqiang Z (2016) DELLA-PIF modules: old dogs learn new tricks. Trends Plant Sci. 21 (10): 813-815.

Zhou Z, Liang K, Xu D, Zhang Y, Huang G, Ma H (2012) Effects of calcium, boron and nitrogen fertilization on the growth of teak (Tectona grandis) seedlings and chemical property of acidic soil substrate. New Forest. 43 (2): 231-243. 